\title{
Nanoscale Separations Combined with Electrospray Ionization Mass Spectrometry: Sulfonamide Determination
}

\author{
John R. Perkins, Carol E. Parker, and Kenneth B. Tomer \\ Laboratory of Molecular Biophysics, National Institute of Environmental Health Sciences, Research Triangle \\ Park, North Carolina, USA
}

\begin{abstract}
Nanoscale capillary liquid chromatography (nCLC) and capillary zone electrophoresis (CZE) have been combined with quadrupole mass spectrometry via an electrospray ionization (ESI) interface. These methodologies have been applied to the separation and determination of a variety of sulfonamides. CZE/ESI/MS is the more rapid and sensitive technique, but nCLC/ESI/MS shows promise for the analysis of dilute samples. Ultimately, the two techniques provide complementary methods of analysis. The detection limits of these techniques in the full-scan mode are in the low picomole range. Dissociation of the sulfonamides can be induced by increasing the skimmer voltage. This provides a limited means of discriminating between compounds of identical molecular weight but, more important, provides fragments that could be used to confirm the presence of analyte within a sample. (J Am Soc Mass Spectrom 1992, 3, 139-149)
\end{abstract}

$\mathrm{I}$ n animal husbandry it has proved necessary to administer a variety of antibiotics for therapeutic purposes or to promote growth. One such group of antibiotics is the sulfonamides, which are active against a wide range of organisms and have been used to combat infection in swine, cattle, honeybees, and fish [1-4]. They have also been administered in subtherapeutic doses to promote growth $[5,6]$. Concern has arisen about ingestion of the drugs in tissues or milk by humans, because the potential for acquired resistance exists [7], and sulfamethazine has recently been identified as a possible carcinogen [8]. Current U.S. government regulations specify a residue limit of $0.1 \mathrm{ppm}$ in animals, wherein swine liver is quoted as the tissue of prime interest $[9,10]$. This means that sensitive analytical methods are required to screen for sulfonamide residues.

Numerous analytical methods exist for sulfonamide residues in meat, including thin-layer chromatography (TLC), which is subject to interference [11], although quantitation has been aided by the introduction of high speed automated TLC scanners [12]. Gas chromatographic methods are limited by the nonvolatile nature of the sulfonamides. Therefore, the formation of the $\mathrm{N}_{1}$-acyl or $\mathrm{N}_{1}$-methyl derivatives is required prior to analysis [13]. Mass spectrometric methods have included the use of collision-activated

Address reprint requests to Kenneth B. Tomer, Laboratory of Molec ular Biophysics, National Institute of Environmental Health Sciences, Research Triangle Park, NC 27709. dissociation (CAD) tandem mass spectrometry (MS/MS) to screen for sulfonamides in swine tissue by direct analysis without a prior chromatographic step $[9,13]$.

The determination of sulfonamides by supercritical fluid chromatography/mass spectrometry (SFC/MS) has also been reported using a moving belt interface with ammonia chemical ionization [14] or with electron ionization, where low nanogram amounts of sulfamethazine were detected in a porcine kidney extract [15]. A mixture of four standards was also chromatographed on-line using a modified thermospray interface [15].

Many methods of high performance liquid chromatography (HPLC) have been investigated employing a variety of stationary phases and mobile phases for the determination of mixtures of sulfonamide standards, sulfonamides and their metabolites, and in a variety of matrices $[4,8,11,16-18]$. Ultraviolet and fluorescence detectors have been most routinely used but, where interferences have arisen, confirmation of analyte identity has been obtained through gas chromatography (GC)/MS, thus introducing problems associated with GC analysis [19]. Use of LC direct liquid introduction/MS/MS with an atmospheric pressure ionization source has been reported for the determination of these compounds. In these experiments $10 \%$ of the chromatographic eluent from a standard $4.6-\mathrm{mm}$ i.d. column was split to the mass spectrometer [20]. The use of ion spray ionization with splitting of the eluent from a $4.6-\mathrm{mm}$ i.d. column or introduction of 
all the eluent from 2- or 1-mm i.d. columns has also been reported [21].

There has been a significant trend in separation science methodologies towards miniaturization as exemplified by the development of open tubular capillary columns for gas chromatographic separations. Use of narrower bore columns has also been investigated in LC in conjunction with mass spectrometry where the lower flow rates can be introduced to the mass spectrometer without postcolumn splitting. The coupling of microbore LC with ion spray and electrospray mass spectrometry has been reported for column diameters of $1 \mathrm{~mm}$ [22-36], $500 \mu \mathrm{m}$ [37], $320 \mu \mathrm{m}$ [37], and $250 \mu \mathrm{m}[38,39]$, where the flow rates employed are in the low microliter per minute range. Applications of microbore LC/electrospray ionization (ESI)/MS include the determination of peptide and protein standards $[22,26,30,34-39]$; tryptic digests [26, 27, 34, 37-39]; sulfonated azo dyes [22, 23]; steroid sulfates [25, 28]; oligosaccharides, glycopeptides, and glycoproteins [31]; synthetic estrogens [22, 24]; marine toxins $[29,32,33]$, adenosine; and methyl red [24]. Our interest in this trend has been in the development of miniaturized separation techniques in LC, i.e., nanoscale LC separation techniques, in conjunction with mass spectrometric detection [40-51]. These nanoscale separation techniques are characterized by liquid flow rates that are in the nanoliter per minute rather than microliter per minute range, and include packed capillary LC (50- or $75-\mu \mathrm{m}$ i.d. columns) ( $\mathrm{nCLC}$ ) and capillary zone electrophoresis (CZE) [52].

CZE was initially coupled with electrospray mass spectrometry by Smith and co-workers [53] in 1987. They demonstrated the on-line separation of quaternary ammonium salts, nucleosides, and peptides where the total column effluent was introduced to the mass spectrometer with no additional makeup flow $[53,54]$. Subsequent interfaces made use of additional makeup flow, by using either a coaxial flow delivery system [37, 55-63] or a liquid junction coupling [64-69], to provide extra flow because electrospray requires a minimum flow rate greater than the usual operating flow rates of CZE [55]. The on-line separations of peptides and proteins [38, 56-67, 69], tryptic digests $[66,67,69]$, quaternary phosphonium salts [55], amines [55], sulfonated azo dyes [66, 68, 69], acid pesticides [66], and benzodiazepines [69] have been shown.

CZE [70] and micellar electrokinetic capillary chromatography [71] of sulfonamides with ultraviolet detection have been reported. CZE with ion spray mass spectrometric detection using a make-up flow provided through a liquid junction coupling has also been shown where six sulfonamides were separated at the 2-pmol level using selected ion monitoring [69].

In a continuation of our interest in the application of nanoscale separation techniques with mass spectrometric analyses, we have studied the separation of mixtures of sulfonamides by nCLC by using $75 \mu \mathrm{m}$ i.d. packed capillary columns and CZE, both combined with ESI/MS.

\section{Experimental}

\section{Mass Spectrometer and Interface}

The mass spectrometer/data system used was a VG 12-250 quadrupole mass spectrometer and data system (VG/Fisons, Altrincham, UK). The mass range employed for flow injection analysis was 50-350 u with a peak width of $1.0 \mathrm{u}$ (VG tune parameter) at 15 $s$ per scan to aid detection of ions of low relative abundance. On-line spectra were acquired over 150-500 $u$ at $5 \mathrm{~s}$ per scan for the nCLC/ESI/MS and 230-350 u at $1 \mathrm{~s}$ per scan for CZE/ESI/MS with a peak width of $1.5 \mathrm{u}$ ( $50 \%$ valley). The mass range was reduced for the CZE experiments because we were interested in screening for molecular ions under the set experimental conditions and because of the potentially narrow peaks encountered in CZE. A Sun 3/60 workstation (Sun Microsystems Inc., Mountain View, CA) employing Mach 3 software (Kratos Analytical, Barton Dock, Manchester, UK) was used for the data reduction from the CZE/ESI/MS experiments. Data were acquired in the continuum (profile) mode for the CZE/ESI/MS and flow injection analysis experiments and in the peak centroid mode for the nCLC/ESI/MS experiments. Peak clusters are often observed at peak width $1.5 \mathrm{u}$ because of the peak detection algorithms employed in the peak centroid mode.

A Vestec electrospray source, model 611B (Vestec Corp., Houston, TX), was used throughout the experiments. This source differs from other electrospray sources in that it does not rely on the use of a nitrogen curtain gas for desolvation, but instead, utilizes a heated block. The block is held at $266{ }^{\circ} \mathrm{C}$, which heats the electrospray to $-55^{\circ} \mathrm{C}$. The needle voltage was held at $\sim 3 \mathrm{kV}$ giving a spray current of $0.250 \mu \mathrm{A}$. The skimmer voltage was held at $+11 \mathrm{~V}$ for the on-line CZE/ESI/MS and nCLC/ESI/MS experiments and was varied between +4 and $+75 \mathrm{~V}$ for the fragmentation experiments.

The probe utilized was of a coaxial flow design. The concept of coaxial flow for use with capillary columns was originally developed for the postcolumn derivatization of analytes after capillary chromatography where the introduction of additional solution could be delivered to the capillary tip without loss of chromatographic resolution [72]. We adapted the coaxial system reported by Rose and Jorgenson [73] for postcapillary fluorescent detection for interfacing nCLC and CZE with continuous-flow fast-atom bombardment (FAB) $[46,48]$. Contemporaneous with these reports, Smith et al. [55] reported the development of a coaxial flow interface for CZE in combination with electrospray. Based on our experience with nCLC/CZE coaxial continuous-flow FAB and on the success observed by Smith et al. [55], we adapted the 
commercial Vestec probe to accommodate a coaxial sheath flow. In our CZE/nCLC probe, the analytical capillary passes through a Valco (Valco Instruments Co. Inc., Houston, TX) "tee," a 1/16-in. stainless steel tube and through the union holding the electrospray needle in place. The analytical capillary column protrudes slightly from the end of the needle. Sheath flow is introduced through one side of the "tee" and flows through the interstitial space between the analytical column and the stainless steel tubing, union, and needle before emerging at the needle tip. The electrospray needle is a piece of stainless steel tubing, 0.013 in. o.d. $\times 0.007$ in. i.d. The electrical connection to the needle is made at the Valco "tee" and the original metal "sleeve" around the probe handle has been replaced with plexiglass to prevent electrical discharge. This electrospray probe design allows separations to be performed at submicroliter flow rates while total flow at the needle tip can be kept at the $\sim 5-10-\mu \mathrm{L} / \mathrm{min}$ rate required for stable electrospray operation.

\section{CZE System}

The CZE system was constructed in-house and has been described elsewhere [47, 74]. It utilizes a Glassman HV power supply (Glassman High Voltage, Whitehouse Station, NJ) which is operated at +30 $\mathrm{kV}$. The high voltage end of the CZE capillary is located in a plexiglass box, while the CZE "ground" is the electrospray needle itself, giving an effective voltage drop of $-27 \mathrm{kV}$.

Injections were made by gravity where the capillary was placed in a sample vial held at a fixed distance above the CZE buffer for a timed interval. The end of the capillary was then placed into the CZE buffer and the voltage was applied to begin the electrophoretic separation. The electroosmotic flow rate was measured at $325 \mathrm{~nL} / \mathrm{min}$. The makeup sheath flow is generated using a Gilson HPLC system with model 302 pumps (Gilson Medical Electronics, Middleton, WI). The column was a 75- $\mu \mathrm{m}$ i.d., $150-\mu \mathrm{m}$ o.d. fused silica tube, and the buffer employed for separations was $0.01 \mathrm{M}$ ammonitum acetate at $\mathrm{pH} 7$.

\section{$n C L C$ System}

Mobile-phase flow through the analytical column was generated using a Gilson gradient HPLC system and controller operating at $0.8 \mathrm{~mL} / \mathrm{min}$. Flow through the capillary column was reduced by a factor of -1000 with a splitting "tee." A $34 \mathrm{~cm}$ length of $75-\mu \mathrm{m}$ i.d. capillary was used to provide the back pressure required to force $\sim 800 \mathrm{~nL} / \mathrm{min}$ of mobile-phase flow through the capillary column. The column preparation procedure has been described in detail elsewhere [42]. After preparation of a frit at the end of the capillary, the first $25 \mathrm{~cm}$ of a $2-\mathrm{m}$ length of $75-\mu \mathrm{m}$ i.d. $150-\mu \mathrm{m}$ o.d. fused silica capillary was packed with
10- $\mu \mathrm{m}$ AQ-C18 (YMC Inc., Morris Plains, NJ). The extra length of fused silica before the column packing allowed easy manipulation of the column and probe.

A water/acetonitrile gradient was employed for the separation. As with CZE/ESI/MS, a sheath flow consisting of 50:50 methanol/3\% aqueous acetic acid was used. The sheath flow was delivered using a Harvard syringe pump, model 909 (Harvard Apparatus Co., Inc., South Natick, MA).

Injections onto the analytical column were performed by placing the end of the column into the sample vial in a stainless steel pressure vessel. Samples were forced onto the column by pressurizing with helium for a timed interval [43].

\section{Chemicals}

The structures of the sulfonamides studied, with their corresponding abbreviations (q.v.), are shown in Figure 1. Standard samples of these compounds were obtained form Sigma Chemical Co. (St. Louis, MO) and Aldrich Chemical Co. (Milwaukee, WI). Mobile phases employed HPLC grade acetonitrile and methanol (Fisher Scientific Co., Fairlawn, NJ). Water was obtained from a Milli-Ro/Milli-Q system (Millipore Corp., Bedford, MA). Trifluoroacetic acid (TFA) was obtained from Fairfield Chemical Co. (Blythewood, SC). The HPLC grade acetic acid was purchased from J.T. Baker Chemical Co. (Phillipsburg, NJ).

\section{Results and Discussion}

Electrospray spectra were obtained from the sulfonamide standards by the continuous flow of standard solutions in ammonium hydroxide $(0.01 \mathrm{M})$ through a $75-\mu \mathrm{m}$ i,d. open capillary tube. Ammonium hydroxide was chosen because dissolution of the sulfonamides occurred more readily than in water and no effect was seen on the mass spectrum in terms of the nature or abundance of ions. While tuning for maximum signal from the protonated molecule ion, it was noted that the optimum skimmer voltage was $+11 \mathrm{~V}$, and that some fragmentation could be induced at higher skimmer voltage settings. This effect was initially utilized in atmospheric pressure ionization sources where voltages were applied to aid declustering. Increasing this declustering voltage was found to produce CAD fragmentation of analytes whete the yields of fragment ions were increased relative to those produced in a quadrupole collision cell $[75,76]$. Loo et al. [77] have noted that changes in the voltage on the skimmer had an effect on energetic collisions in the nozzle -skimmer region in the electrospray source. For multiply charged ions, higher voltages favored the observation of species with fewer charges which was found to be consistent with a CAD process [77]. This phenomenon has also been demonstrated using a thermospray interface where the the position and field 


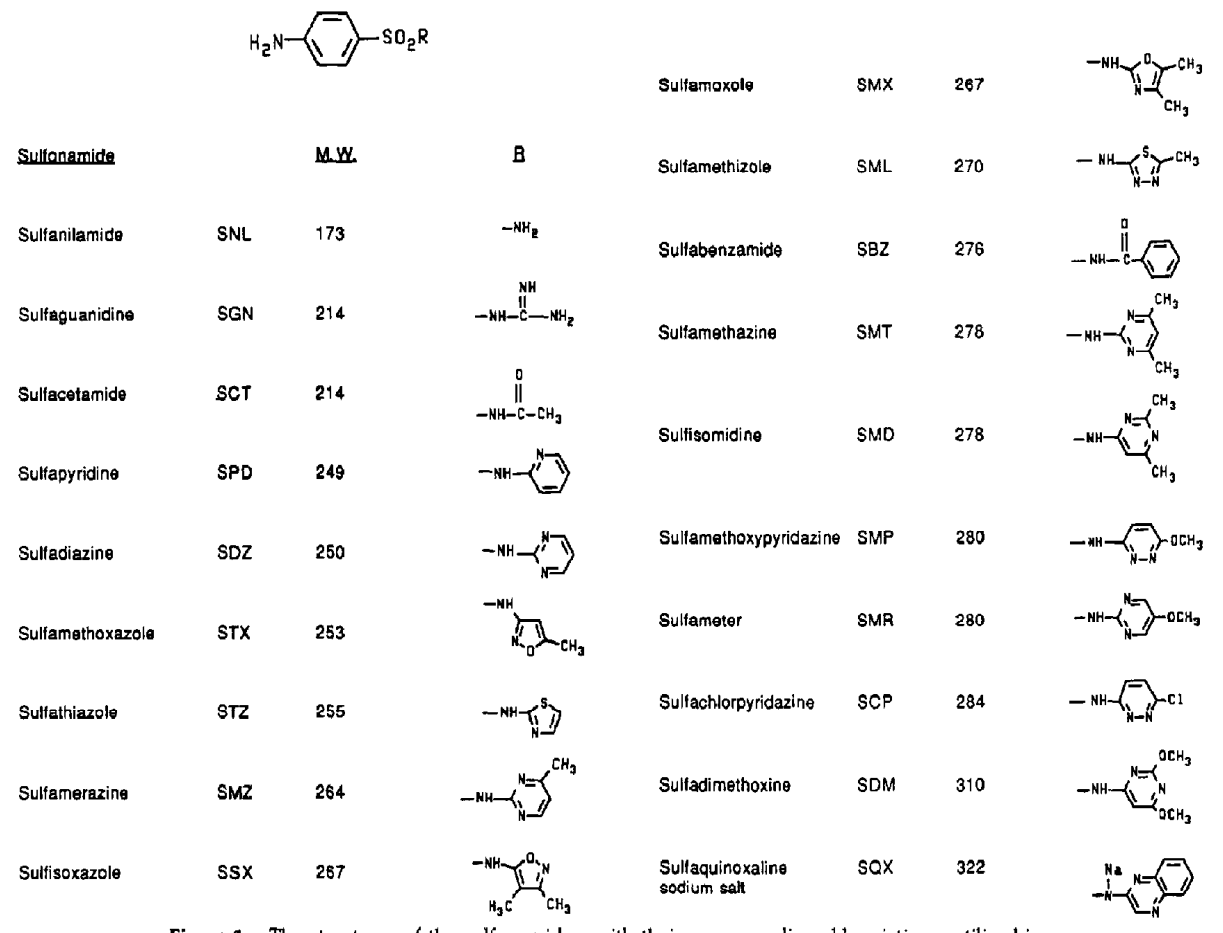

Figure 1. The structures of the sulfonamides, with their corresponding abbreviations, utilized in this study.

strength of the repeller affected the sensitivity and fragmentation [78-80]. The induction of fragmentation of protonated molecules, formed by ESI, by altering the repeller/skimmer has been shown for quadropole [81-84] and ion trap mass spectrometers [85]. CAD spectra have been acquired for peptides [81], proteins [83, 84], ruthenium complexes [82], and porphyrins [85] using this method. The fragments seen for the sulfonamides were predictable and comparable to those seen by CAD MS/MS [13]. Typical spectra for sulfisoxazole (SSX) between the skimmer voltage settings of +4 and $+75 \mathrm{~V}$ are shown in Figure 2 and the origin of SSX fragments are shown in Scheme I. The masses and relative abundance of the sulfonamide fragments obtained at $+11,+25$, and $+40 \mathrm{~V}$ are shown in Table 1 . No value could be placed on the abundance of the $\left(\mathrm{RNHSO}_{2}\right)^{+}$ion of sulfapyridine (SPD) of $m / z=157$, because of the common ion cluster centered around $m / z=156$. Any ions due to the $\left(\mathrm{RNH}_{3}\right)^{+}$group of sulfanilamide (SNL) could not be seen because they were below the mass range of the acquisition. The ion due to the $(\mathrm{M}+\mathrm{H}-$ $\left.\mathrm{SO}_{2}-2 \mathrm{H}\right)^{+}$fragment of sulfamerazine (SMZ) could not be measured due to a background ion of the same mass of $m / z=199$. The base peak in the spectrum of sulfaquinoxaline (SQX) sodium salt of $\mathrm{m} / z=301$ is due to the protonated molecule ion of SQX, where the sodium has been replaced by hydrogen in solution. The presence of an ion of $m / z=146$ is due to the $\left(\mathrm{RNH}_{3}\right)^{+}$fragment from this species.

The majority of the sulfonamides showed the same pattern of rise and fall in the relative abundance of fragments with changing voltage. The protonated molecule formed the spectral base peak for most sulfonamides between skimmer voltages of +4 and +25 V. Above $+25 \mathrm{~V}$, fragmentation was increased and the protonated molecule ion became less significant. All of the sulfonamides formed a daughter of $\mathrm{m} / \mathrm{z}=$ 156 , due to loss of $\left(\mathrm{RNH}_{2}\right)$, which was generally of low abundance at +4 and $+11 \mathrm{~V}$, but it became more important with increasing voltage, forming the spectral base peak for many at $+40 \mathrm{~V}$. Above $+40 \mathrm{~V}$ the relative abundance decreased sharply. This trend was also followed by the $\left(\mathrm{RNH}_{3}\right)^{+}$ion which showed a relative ion abundance of $>50 \%$, for all of the sulfonamides except STX, STZ, SML, SBZ, SCP, and SQX at $+40 \mathrm{~V}$ and the ion of $m / z=108$, which was generally of lower relative abundance but did not show the same rapid decline above $+40 \mathrm{~V}$. At voltages $>+40 \mathrm{~V}$ smaller fragment ions increased in abundance where the ions of $m / z=65$ and 92 tended to dominate spectra. 

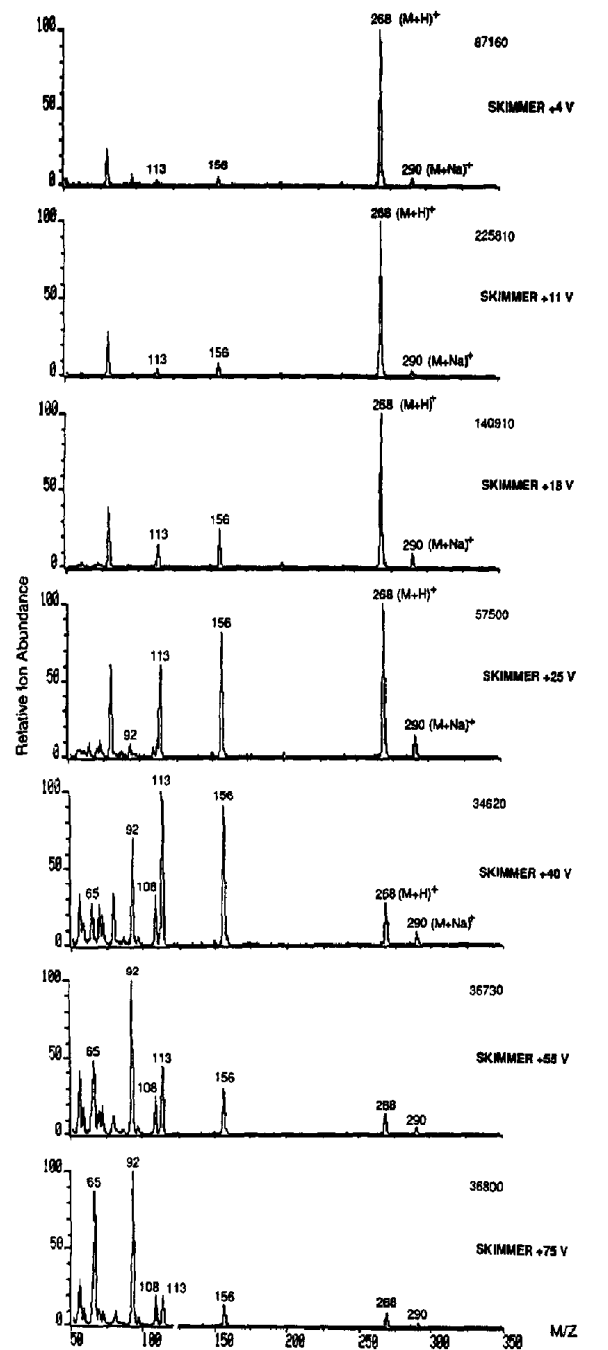

Figure 2. The effect of change in skimmer voltage on the spectra of sulfisoxazole, by flow injection analysis. Needle voltage $=3 \mathrm{kV}$; Spray current $=0.250 \mu \mathrm{A}$; Block temperature $=260$ ${ }^{\circ} \mathrm{C}$; Spray temperature $=55{ }^{\circ} \mathrm{C}$. Spectra were acquired from 50 to $350 \mathrm{u}$ at $15 \mathrm{~s}$ per scan. The values in the top right corner of each spectrum refers to the abundance of the base ion. The apparent resolution in the full-scan plots is artificially degraded owing to the compression algorithms of the platting routine.

Some individual sulfonamides showed some difference from these general trends and it was decided to determine whether isomeric pairs could be differentiated based on their CAD fragmentations. The isomeric pair of sulfamoxole (SMX) and SSX (both having a $M_{\mathrm{r}}=267$ ) showed slight spectral differences<smiles></smiles>

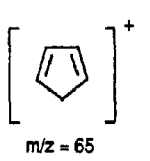<smiles>CCCCCCCCc1c(C)noc1N</smiles>

$\left(\mathrm{PNH}_{3}\right)^{+}$

Scheme I. The CAD fragmentation of the protonated molecule ion of sulfisoxazole [13] together with some species produced during fragmentation [86].

mainly involving the relative abundance of the $\left(\mathrm{RNH}_{3}\right)^{+}$ion of $\mathrm{m} / z=113$ and of the ion of $\mathrm{m} / z=$ 156. At $+25 \mathrm{~V}$ the $\left(\mathrm{RNH}_{3}\right)^{+}$ion of SMX had a higher relative abundance than that of SSX (61\% compared to $18 \%)$. At $+40 \mathrm{~V}$, the base peak in the spectrum of SMX occurred at $m / z=156$ while the $\left(\mathrm{RNH}_{3}\right)^{+}$ion of $m / z=113$ was most abundant for SSX. Very little difference could be observed between sulfamethoxypyridazine (SMP) and sulfameter (SMR) (both having a $M_{\mathrm{r}}=280$ ). The spectra of sulfaguanidine (SGN) and sulfacetamide (SCT) (both having a $M_{r}=214$ ) showed the most obvious differences. At skimmer voltages $<+55 \mathrm{~V}$, the only fragment ion of SGN that showed a relative abundance $>25 \%$ was the $\left(\mathrm{RNH}_{3}\right)^{+}$ion of $m / z=60$, which formed the spectral base peak between +25 and $+75 \mathrm{~V}$. At $+55 \mathrm{~V}$ the ion of $m / z=92\left(\mathrm{C}_{6} \mathrm{H}_{6} \mathrm{~N}\right)^{+}[86]$ showed a relative ion abundance of $43 \%$, and at $+75 \mathrm{~V}$ the ions of $m / z=65$ and 92 showed relative ion abundances of $97 \%$ and $83 \%$, respectively. The ion of $m / z=60$ was of lesser importance for SCT where its relative abundance peaked at $+40 \mathrm{~V}(52 \%)$ and then declined with increasing voltage. The spectral base peak of SCT was due to the ion of $m / z=156$ at +18 and $+25 \mathrm{~V}$, the ion of $m / z=92$ at +40 and $+55 \mathrm{~V}$, and the ion of $m / z=65$ at $+75 \mathrm{~V}$. The spectra of sulfamethazine (SMT) and sulfsomidine (SMD) (both having a $M_{\mathrm{r}}=$ 278) showed major differences between +25 and +75 $\mathrm{V}$. The ion of $m / z=124$, due to the $\left(\mathrm{RNH}_{3}\right)^{+}$group, was of high relative abundance for $\mathrm{SMD}$ and dominated the spectra at +40 and $+55 \mathrm{~V}$. It also formed the spectral base peak for SMT at $+40 \mathrm{~V}$, but the major difference was in the relative abundance of other diagnostic fragments. For SMD all other ions 
Table 1. The masses, relative abundances and origins of the sulfonamide fragments obtained at skimmer voltages of $+11,+25$, and $+40 \mathrm{~V}$. Experimental conditions as in Figure 2 .

\begin{tabular}{|c|c|c|c|c|c|c|c|c|c|c|c|c|c|}
\hline & Votleg" & $(M+N a)^{*}$ & $\left(\mathrm{M}_{+}+\mathrm{NH}_{4}\right)^{+}$ & $(M+H)^{+}$ & $\left(\mathrm{M}+\mathrm{H}-\mathrm{SO}_{2}-2 \mathrm{H}\right)$ & $1^{+}\left(\mathrm{FNHSO}_{2}\right)^{+}$ & $\left(\mathrm{FNHH}_{3}\right)^{+}$ & $m / 2=156$ & $m / 2=108$ & $m / 2-92$ & $m / 2-65$ & \multirow{2}{*}{\multicolumn{2}{|c|}{$\begin{array}{l}\text { Oaher lons } \\
3<5(3)\end{array}$}} \\
\hline She & $\begin{array}{l}11 \\
25 \\
40\end{array}$ & $\begin{array}{l}195(13) \\
195(10) \\
195(4)\end{array}$ & $\begin{array}{l}191(49) \\
19 t(8) \\
191(6)\end{array}$ & $\begin{array}{l}173(100) \\
173(37) \\
173(16)\end{array}$ & $\begin{array}{l}101 \\
101 \\
101\end{array}$ & $\begin{array}{l}(0) \\
10) \\
(0)\end{array}$ & $\begin{array}{l}N / A \\
N / A \\
N / A\end{array}$ & $\begin{array}{c}(42) \\
(100) \\
(25)\end{array}$ & $\begin{array}{l}(9) \\
(19) \\
(32)\end{array}$ & $\begin{array}{c}(0) \\
(34) \\
(100)\end{array}$ & $\begin{array}{l}(0) \\
(b) \\
(47)\end{array}$ & & \\
\hline $\mathrm{sa \textrm {N }}$ & $\begin{array}{l}11 \\
23 \\
40\end{array}$ & $\begin{array}{l}237(8) \\
237(6) \\
237(4)\end{array}$ & $\begin{array}{l}101 \\
10) \\
10)\end{array}$ & $\begin{array}{l}215(100\} \\
215(45) \\
215(12)\end{array}$ & $\begin{array}{l}10) \\
101 \\
101\end{array}$ & $\begin{array}{l}(0) \\
10) \\
10)\end{array}$ & $\begin{array}{l}60(15) \\
60(100) \\
60(100)\end{array}$ & $\begin{array}{l}(11) \\
(19) \\
(15)\end{array}$ & $\begin{array}{l}\text { (0) } \\
\text { (0) } \\
\text { (5) }\end{array}$ & $\begin{array}{l}101 \\
101 \\
(12)\end{array}$ & $\begin{array}{l}(0) \\
(0) \\
(5)\end{array}$ & & \\
\hline SGT & $\begin{array}{l}11 \\
25 \\
40\end{array}$ & $\begin{array}{l}297(15) \\
237(10) \\
237(4)\end{array}$ & $\begin{array}{l}233(33) \\
233(5) \\
233(6)\end{array}$ & $\begin{array}{l}215(100) \\
215(23) \\
215(13)\end{array}$ & $\begin{array}{l}101 \\
101 \\
105\end{array}$ & $\begin{array}{l}(0) \\
10) \\
(0)\end{array}$ & $\begin{array}{l}60(6) \\
60(11) \\
60(52)\end{array}$ & $\begin{array}{l}(31) \\
(100) \\
(74)\end{array}$ & 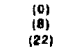 & $\begin{array}{c}10\} \\
\{15\} \\
(100)\end{array}$ & $\begin{array}{l}(6) \\
(3) \\
(24)\end{array}$ & & \\
\hline SPO & $\begin{array}{l}11 \\
25 \\
40\end{array}$ & $\begin{array}{l}272(5) \\
272(14) \\
272(8)\end{array}$ & $\begin{array}{l}\text { (0) } \\
0 \\
(0)\end{array}$ & $\begin{array}{l}250(100) \\
250(100) \\
250(24)\end{array}$ & $\begin{array}{c}(0) \\
+84(13) \\
184(28)\end{array}$ & $\begin{array}{l}\mathbf{N} / \mathbf{A} \\
\mathbf{N} / \mathbf{A} \\
\mathbf{N} / \mathbf{A}\end{array}$ & $\begin{array}{c}(0) \\
95517) \\
55(62)\end{array}$ & $\begin{array}{l}(3) \\
(52) \\
(95)\end{array}$ & $\begin{array}{l}\text { (0) } \\
(\mathbf{6}) \\
(53)\end{array}$ & $\begin{array}{l}(0) \\
(7) \\
(100)\end{array}$ & $\begin{array}{l}(0) \\
10) \\
(0)\end{array}$ & & \\
\hline $\mathbf{s p z}$ & $\begin{array}{l}11 \\
28 \\
40\end{array}$ & $\begin{array}{l}273(6) \\
273(17) \\
273(10)\end{array}$ & $\begin{array}{l}(0) \\
\text { (0) } \\
(0)\end{array}$ & $\begin{array}{l}251(100) \\
251(100) \\
251(54)\end{array}$ & $\begin{array}{c}(0) \\
(0) \\
185(5)\end{array}$ & $\begin{array}{c}(0) \\
158(9) \\
158(14)\end{array}$ & $\begin{array}{c}(0) \\
0 \theta(+6) \\
0 \theta(54)\end{array}$ & $\begin{array}{c}(5) \\
(60) \\
(100)\end{array}$ & $\begin{array}{l}\text { (야) } \\
\text { (9) } \\
\text { (3) }\end{array}$ & $\begin{array}{l}\text { (0) } \\
\text { (i1) } \\
\text { (76) }\end{array}$ & $\begin{array}{l}\text { (0) } \\
\text { (5) } \\
\text { (15) }\end{array}$ & & \\
\hline STX & $\begin{array}{l}11 \\
23 \\
40\end{array}$ & $\begin{array}{c}278(8) \\
278(12) \\
278(0)\end{array}$ & $\begin{array}{l}(0) \\
01 \\
01\end{array}$ & $\begin{array}{l}254(100) \\
2541100) \\
254(67)\end{array}$ & $\begin{array}{c}(9) \\
188(5) \\
188(12)\end{array}$ & $\begin{array}{l}101 \\
001 \\
\langle 0|\end{array}$ & $\begin{array}{l}(0) \\
99(6) \\
09(35)\end{array}$ & $\begin{array}{c}\text { (4) } \\
(37) \\
(100)\end{array}$ & $\begin{array}{l}(0) \\
\text { (5) } \\
\text { (37) }\end{array}$ & $\begin{array}{l}\text { (0) } \\
\text { (9) } \\
\text { (89) }\end{array}$ & $\begin{array}{l}\text { (0) } \\
\text { (4) } \\
\text { (12) }\end{array}$ & & \\
\hline STZ & $\begin{array}{l}11 \\
25 \\
40\end{array}$ & $\begin{array}{l}278(5) \\
278(10) \\
278(10)\end{array}$ & $\begin{array}{l}\text { (0) } \\
\text { (0) } \\
(0)\end{array}$ & $\begin{array}{l}258(100) \\
256(100) \\
256(55)\end{array}$ & $\begin{array}{l}(0) \\
0 \\
101 \\
101\end{array}$ & $\begin{array}{l}(0) \\
001 \\
(0)\end{array}$ & $\begin{array}{c}(0) \\
101(5) \\
101(17)\end{array}$ & $\begin{array}{c}(7) \\
(80) \\
(100)\end{array}$ & $\begin{array}{l}(0) \\
\text { (A) } \\
|2 B|\end{array}$ & $\begin{array}{l}(0) \\
(8) \\
(81)\end{array}$ & $\begin{array}{l}\text { (0) } \\
\text { (B) } \\
\text { (11i) }\end{array}$ & & \\
\hline SWR & $\begin{array}{l}11 \\
25 \\
40\end{array}$ & $\begin{array}{c}287(5) \\
287(10) \\
287(11)\end{array}$ & $\begin{array}{l}10\} \\
(0) \\
(0)\end{array}$ & $\begin{array}{l}285(100) \\
265(100) \\
265(49)\end{array}$ & $\begin{array}{l}N / A \\
N / A \\
N / A\end{array}$ & $\begin{array}{c}(0) \\
172(21) \\
172(38)\end{array}$ & $\begin{array}{c}(0) \\
110(13) \\
110(83)\end{array}$ & $\begin{array}{l}\text { (d) } \\
\text { (av) } \\
(100)\end{array}$ & $\begin{array}{l}(0) \\
(4) \\
(54)\end{array}$ & $\begin{array}{l}(0) \\
(5) \\
(93)\end{array}$ & $\begin{array}{c}(0) \\
(3) \\
(10)\end{array}$ & & \\
\hline ss $x$ & $\begin{array}{l}11 \\
25 \\
40\end{array}$ & $\begin{array}{c}290(6) \\
290(16) \\
290(9)\end{array}$ & $\begin{array}{l}(0) \\
(0) \\
(0)\end{array}$ & $\begin{array}{l}268(100) \\
268(100) \\
268(28)\end{array}$ & $\begin{array}{l}(0) \\
(0) \\
(0)\end{array}$ & $\begin{array}{l}101 \\
101 \\
(0)\end{array}$ & $\begin{array}{c}113(5) \\
113(81) \\
113(100)\end{array}$ & $\begin{array}{l}\text { (9) } \\
\text { (a2) } \\
\text { (01) }\end{array}$ & $\begin{array}{l}(0) \\
(8) \\
(34)\end{array}$ & $\begin{array}{l}(2) \\
(10) \\
(70)\end{array}$ & $\begin{array}{l}\text { (0) } \\
(9) \\
(29)\end{array}$ & & \\
\hline simx & $\begin{array}{l}11 \\
25 \\
40\end{array}$ & $\begin{array}{l}290(1) \\
290(12) \\
200(15)\end{array}$ & $\begin{array}{l}10 \\
(0) \\
(0)\end{array}$ & $\begin{array}{l}2 B B(100) \\
2 B(100) \\
2 B B(53)\end{array}$ & $\begin{array}{l}\text { (0) } \\
101 \\
(0)\end{array}$ & $\begin{array}{l}(0) \\
(0) \\
(0)\end{array}$ & $\begin{array}{l}113(9) \\
113(18) \\
113(74)\end{array}$ & $\begin{array}{l}(6) \\
(53) \\
(100)\end{array}$ & $\begin{array}{l}(0) \\
15) \\
(30)\end{array}$ & $\begin{array}{l}\text { (0) } \\
\text { (6) } \\
\text { (B1) }\end{array}$ & $\begin{array}{l}(0) \\
(4) \\
(22)\end{array}$ & $\begin{array}{l}140(4) \\
140(7)\end{array}$ & \\
\hline SM & $\begin{array}{l}11 \\
25 \\
40\end{array}$ & $\begin{array}{r}293(3) \\
20347) \\
203(129\end{array}$ & $\begin{array}{l}(0) \\
(0) \\
(0)\end{array}$ & $\begin{array}{l}271(100) \\
27(100) \\
27(13)\end{array}$ & $\begin{array}{l}\text { (0) } \\
\text { (0) } \\
\text { (0) }\end{array}$ & $\begin{array}{l}\text { (d) } \\
178(2) \\
(B)\end{array}$ & $\begin{array}{c}(0) \\
(0) \\
118(5)\end{array}$ & $\begin{array}{r}(10) \\
(60) \\
(100)\end{array}$ & $\begin{array}{l}(0) \\
(3) \\
(29)\end{array}$ & $\begin{array}{l}(0) \\
(6) \\
(61)\end{array}$ & $\begin{array}{l}\text { (0) } \\
(5) \\
(14)\end{array}$ & & \\
\hline s8z & $\begin{array}{l}11 \\
25 \\
40\end{array}$ & $\begin{array}{c}299(5) \\
299(11) \\
2901 B)\end{array}$ & $\begin{array}{l}295(5) \\
295(4) \\
295(7)\end{array}$ & $\begin{array}{l}277(100) \\
277155\} \\
277(27)\end{array}$ & $\begin{array}{l}\text { (0) } \\
\text { (0) } \\
\text { (0) }\end{array}$ & $\begin{array}{l}(0) \\
(0) \\
(0)\end{array}$ & $\begin{array}{l}(0) \\
(0) \\
10)\end{array}$ & $\begin{array}{l}(15) \\
(190) \\
(100)\end{array}$ & $\begin{array}{l}\text { (0) } \\
\text { (6) } \\
\text { (34) }\end{array}$ & $\begin{array}{l}(0) \\
\text { (10) } \\
(11)\end{array}$ & $\begin{array}{l}(0) \\
(9) \\
(10)\end{array}$ & & \\
\hline SMT & $\begin{array}{l}11 \\
25 \\
40\end{array}$ & $\begin{array}{c}301(14) \\
301(8) \\
301(14)\end{array}$ & $\begin{array}{l}10\} \\
10\} \\
(0)\end{array}$ & $\begin{array}{l}2791100) \\
279(100) \\
279(43)\end{array}$ & $\begin{array}{c}(0) \\
213(1) \\
213(8)\end{array}$ & $\begin{array}{l}186(2) \\
186(24) \\
186(87)\end{array}$ & $\begin{array}{c}(0) \\
124(8) \\
124(100)\end{array}$ & $\begin{array}{l}\text { (1) } \\
\text { (12) } \\
(79)\end{array}$ & $\begin{array}{l}\text { (0) } \\
(2) \\
(45)\end{array}$ & $\begin{array}{l}(0) \\
(2) \\
(65)\end{array}$ & $\begin{array}{l}(0) \\
(0) \\
(0)\end{array}$ & & \\
\hline SMD & $\begin{array}{l}11 \\
25 \\
40\end{array}$ & $\begin{array}{l}301(1) \\
301(5) \\
301(4)\end{array}$ & $\begin{array}{l}(9) \\
00 \\
00\end{array}$ & $\begin{array}{l}278(100) \\
279(100) \\
279(20)\end{array}$ & $\begin{array}{l}101 \\
01 \\
10\}\end{array}$ & $\begin{array}{l}186(9) \\
186(19) \\
186(22)\end{array}$ & $\begin{array}{c}124(3) \\
124(31) \\
124(100)\end{array}$ & $\begin{array}{l}\text { (1) } \\
\text { (9) } \\
(23)\end{array}$ & $\begin{array}{l}(9) \\
(0) \\
(10)\end{array}$ & $\begin{array}{l}(0) \\
(0) \\
(16)\end{array}$ & $\begin{array}{l}(0) \\
(1) \\
(10)\end{array}$ & & \\
\hline SMP & $\begin{array}{l}11 \\
25 \\
40\end{array}$ & $\begin{array}{c}303(6) \\
303(16) \\
303(18)\end{array}$ & $\begin{array}{l}\text { (0) } \\
\text { (1) } \\
\text { (0) }\end{array}$ & $\begin{array}{l}281(100) \\
281(100) \\
281(20)\end{array}$ & $\begin{array}{c}10) \\
215(3) \\
215(4)\end{array}$ & $\begin{array}{c}10) \\
188(4) \\
188(4)\end{array}$ & $\begin{array}{c}128(2) \\
128(16) \\
126(80)\end{array}$ & $\begin{array}{c}(5) \\
(40) \\
(100)\end{array}$ & $\begin{array}{l}(0) \\
(5) \\
(38)\end{array}$ & $\begin{array}{l}10) \\
(71) \\
(70)\end{array}$ & $\begin{array}{l}\text { (0) } \\
(0) \\
\text { (12) }\end{array}$ & & \\
\hline SAF & $\begin{array}{l}11 \\
25 \\
40\end{array}$ & $\begin{array}{c}303(0) \\
303(11) \\
303(23)\end{array}$ & $\begin{array}{l}\text { (0) } \\
\text { (o) } \\
\text { (0) }\end{array}$ & $\begin{array}{l}281(100) \\
281(100) \\
281(71)\end{array}$ & $\begin{array}{c}101 \\
215(18) \\
215(23)\end{array}$ & $\begin{array}{c}(0) \\
188(7) \\
188(23)\end{array}$ & $\begin{array}{c}(0) \\
128(7) \\
128(81)\end{array}$ & $\begin{array}{l}(4) \\
(23) \\
(100)\end{array}$ & $\begin{array}{l}10) \\
13) \\
(148)\end{array}$ & $\begin{array}{l}(0) \\
(4) \\
(03)\end{array}$ & $\begin{array}{l}\text { (0) } \\
\text { (0) } \\
(16)\end{array}$ & & \\
\hline $\mathbf{S C P}$ & $\begin{array}{l}11 \\
25 \\
40\end{array}$ & $\begin{array}{l}307(3) \\
307(1) \\
307(5)\end{array}$ & $\begin{array}{l}\text { (o) } \\
\text { (1) } \\
\text { (0) }\end{array}$ & $\begin{array}{l}285(100) \\
295(100) \\
285(48)\end{array}$ & $\begin{array}{l}(0) \\
(0) \\
(0)\end{array}$ & $\begin{array}{l}(0) \\
101 \\
(0)\end{array}$ & $\begin{array}{c}(0) \\
130(1) \\
130(4)\end{array}$ & $\begin{array}{l}(15) \\
(100) \\
(100)\end{array}$ & $\begin{array}{l}\text { (0) } \\
(7) \\
(28)\end{array}$ & $\begin{array}{l}(0) \\
(0) \\
(55)\end{array}$ & $\begin{array}{l}\text { (0) } \\
\text { (0) } \\
\text { (14) }\end{array}$ & $\begin{array}{l}300(1) \\
300(3) \\
267(13)\end{array}$ & 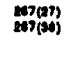 \\
\hline scm & $\begin{array}{l}11 \\
25 \\
40\end{array}$ & $\begin{array}{l}393(5) \\
333(5) \\
333(8)\end{array}$ & $\begin{array}{l}\text { (9) } \\
(0) \\
(0)\end{array}$ & $\begin{array}{l}311(100) \\
311(100) \\
311(57)\end{array}$ & $\begin{array}{c}(0) \\
245(5) \\
245(10)\end{array}$ & $\begin{array}{c}(0) \\
(0) \\
218(B)\end{array}$ & $\begin{array}{l}158(4) \\
158(21) \\
156(100)\end{array}$ & $\begin{array}{l}(4) \\
(21) \\
(100)\end{array}$ & $\begin{array}{l}(0) \\
(3) \\
(21)\end{array}$ & $\begin{array}{l}(0) \\
(0) \\
(30)\end{array}$ & $\begin{array}{l}\text { (0) } \\
\text { (0) } \\
\text { (4) }\end{array}$ & & \\
\hline $50 x$ & $\begin{array}{l}11 \\
25 \\
40\end{array}$ & $\begin{array}{c}345(4) \\
345(5) \\
345(11)\end{array}$ & $\begin{array}{l}\text { (0) } \\
00 \\
00\end{array}$ & $\begin{array}{l}323(30) \\
323(43) \\
323(35]\end{array}$ & $\begin{array}{l}(0) \\
01 \\
01\end{array}$ & $\begin{array}{l}10) \\
101 \\
101\end{array}$ & $\begin{array}{c}(0) \\
145^{(6)}(4) \\
145^{\circ}(20)\end{array}$ & $\begin{array}{l}\text { (8) } \\
\text { (53) } \\
(100)\end{array}$ & $\begin{array}{l}(10) \\
131 \\
(33)\end{array}$ & $\begin{array}{l}(0) \\
\text { (8) } \\
\text { (31) }\end{array}$ & $\begin{array}{l}(0) \\
10) \\
(14)\end{array}$ & $\begin{array}{l}301(100) \\
301(100) \\
301(13)\end{array}$ & \\
\hline
\end{tabular}

were relatively insignificant at $+40 \mathrm{~V}$, with the next most abundant ion present with a relative ion abundance of $23 \%(m / z=156)$. The spectrum of SMT showed several ions with relative ion abundances $>40 \%[m / z=279(43 \%), m / z=186(87 \%), m / z=$ $156(79 \%), m / z=108(45 \%)$, and $m / z=92(65 \%)]$. When the skimmer voltage was increased to $+55 \mathrm{~V}$, the ion of $m / z=92$ dominated the spectrum of SMT, and the ion of $m / z=124$ showed a relative ion abundance of $54 \%$ with the ion of $m / z=108$ also present with a relative ion abundance $>30 \%$. The effect of change of skimmer voltage on the dissociation for SMT and SMD is shown in Figure 3. These CADs may be of relatively limited value for discriminating between compounds of the same mass within a group. They could, however, prove to be valuable when searching for confurmatory data or when screening for sulfonamides as a class, because all of the sulfonamides show fragmentation patterns which follow the same pathways. Raising the skimmer voltage can provide relatively abundant ions due to either the $\left(\mathrm{RNH}_{3}\right)^{+}$ion or loss of $\left(\mathrm{RNH}_{2}\right)$ at +25 and $+40 \mathrm{~V}$ providing specific fragmentations for the sulfonamides. It could be seen that the abundance of the base ion was maximized at a skimmer of $+11 \mathrm{~V}$ where most of the signal was due to the $(\mathrm{M}+\mathrm{H})^{+}$ 

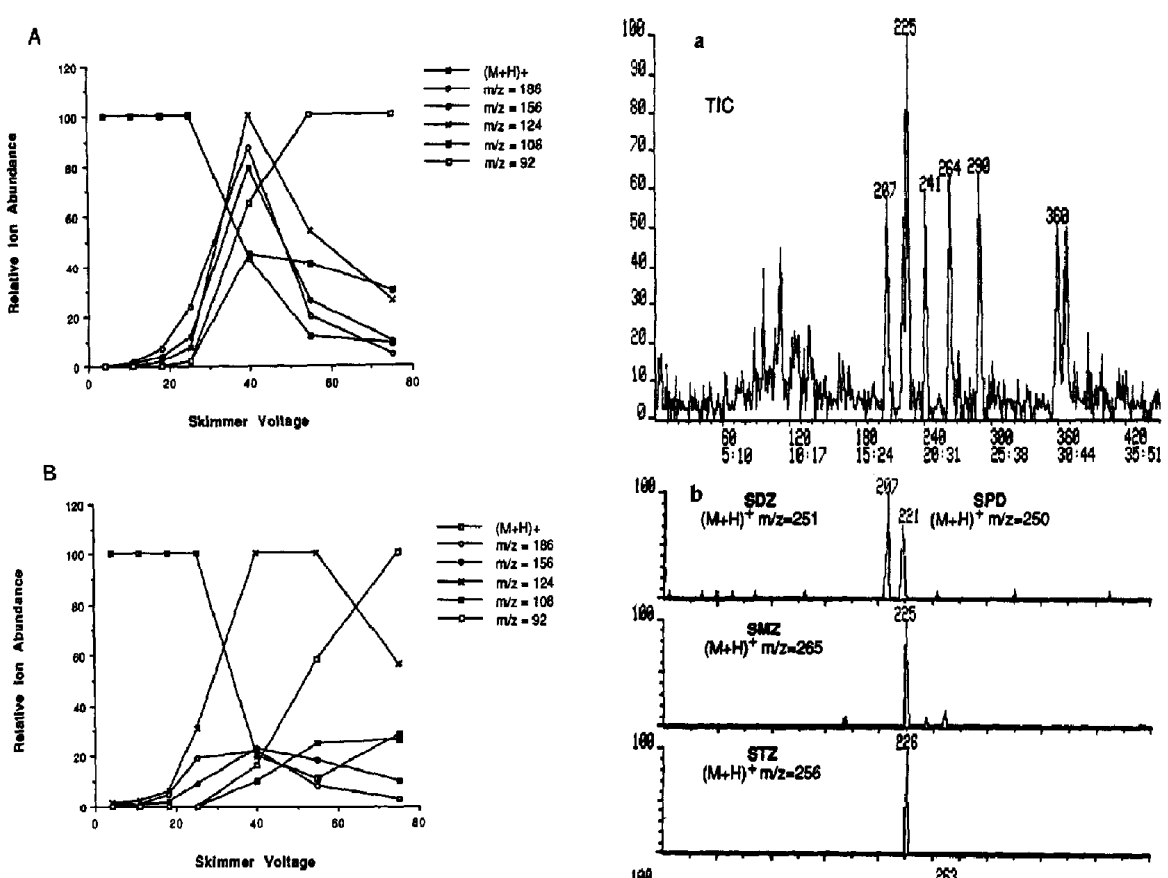

Figure 3. The effect of skimmer voltage on the relative abundance of the six major ions seen for (A) SMT and (B) SMD. Experimental conditions as in Figure 2.

ion; this set our conditions for the on-line experiments.

Our next step was to assess on-line nCLC/ESI/MS by using a $75-\mu \mathrm{m}$ i.d. packed capillary column as an analytical method for the screening of sulfonamides. We initially chromatographed a mixture similar to that run by SFC [15] (SPD, SDZ, STZ, SMZ, SMT, SMP, $\mathrm{SCP}, \mathrm{SDM}$, and SQX) except for sulfadoxine which was unavailable. The concentration of the prepared solution was dilute ( $32 \mathrm{pmol} / \mu \mathrm{L}$ SDM to $40 \mathrm{pmol} / \mu \mathrm{L}$ $\mathrm{SPD}$ ) which meant that preconcentration at the head of the column was required for mass spectrometric detection with typical injection volumes in the 1-3- $\mu \mathrm{L}$ range. This was achieved by injecting the sample in water for a sufficient time interval until there was enough analyte injected to provide a reasonable signal to noise $(S / N)$ ratio and then implementing the chromatographic gradient. This technique can obviously be extended to the screening of actual samples where the sample injection time can be adjusted to be as long or as short as required. The amount injected onto the column of the sulfonamides ranged from $\mathbf{5 2}$ pmol of SQX to $70 \mathrm{pmol}$ of SDZ and SPD. The gradient employed was from $0 \%$ B to $100 \%$ B aver $1 \mathrm{~h}$ where solvent $A$ was water containing $0.1 \%$ TFA and solvent $B$ was acetonitrile containing $0.1 \%$ TFA. The

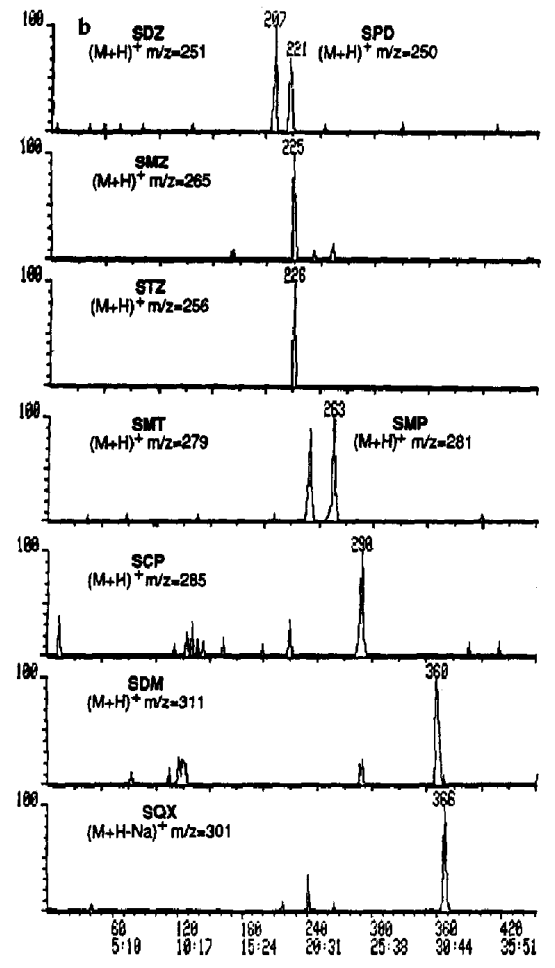

Figure 4. (A) The reconstructed total ion current trace (no background subtraction) obtained from nCLC/ESI/MS of a mix of nine sulfonamides (SDZ, SPD, SMZ, STZ, SMT, SMP, SCP, SDM, SQX). The amount of each injected ranged from $52 \mathrm{pmol}$ SQX to $70 \mathrm{pmol} \mathrm{SDZ}$ and SPD. The column was a 2-m length of $75-\mu \mathrm{m}$ i.d. $150 \mu$ o.d. fused silica capillary tubing with the first $25 \mathrm{~cm}$ packed with $10-\mu \mathrm{m}$ AQ-C18 packing. The mobile phase utilized a gradient from $0 \%$ B to $100 \%$ B over 30 minutes where solvent $A$ was water containing $0.1 \%$ TFA and solvent $B$ was acetonitrile containing $0.1 \%$ TFA. The skimmer voltage was set at $+11 \mathrm{~V}$. Electrospray conditions as in Figure 2 except spectra were acquired from 150 to $500 \mathrm{u}$ at $5 \mathrm{~s}$ per scan. (B) Selected ion chromatograms of the $(\mathrm{M}+\mathrm{H})^{+}$ions of the sulfonamides shown in A. Experimental conditions as in A. 
reconstructed total ion current (TIC) trace for this mixture of nine components shows eight peaks, although the two peaks centered at scans 221 and 225 are not completely resolved (Figure 4a). Chromatograms of the $(\mathrm{M}+\mathrm{H})^{+}$ions of the sulfonamides easily distinguish between the components (Figure $4 b$ ). These show that, although the peaks due to STZ and SMZ can be resolved by their mass spectra, they can only be seen as a single peak on the TIC trace, and SPD is only partially resolved from this peak. On-line spectra showed the protonated molecule ion as the base peak together with the sodiated molecule ion (relative ion abundance $<40 \%$ ).

This methodology was then extended to include all 19 of the standards on hand. The amount injected onto the column ranged from $30 \mathrm{pmol} S Q X$ to 40 pmol SGN and SCT. At these levels it was found that the $(\mathrm{M}+\mathrm{Na})^{+}$ion channel was more useful for several sulfonamides because there was significant noise within the system. Although all of the sulfonamides showed $(\mathrm{M}+\mathrm{Na})^{+}$ions via flow injection analysis, for the on-line analysis, peaks due to sodiated molecule ions were not detected for STZ, SMD, or SQX. The only protonated ion which could not be detected at this level was SCP because a background ion at $m / z=284$ overwhelmed the signal due to the low level of SCP. The relative abundance of the sodiated molecule ion depended on the composition of the mobile phase and was variable with time. It is useful to be aware of the formation of sodium adducts because the sodiated molecule ion may prove useful where interferences exist.
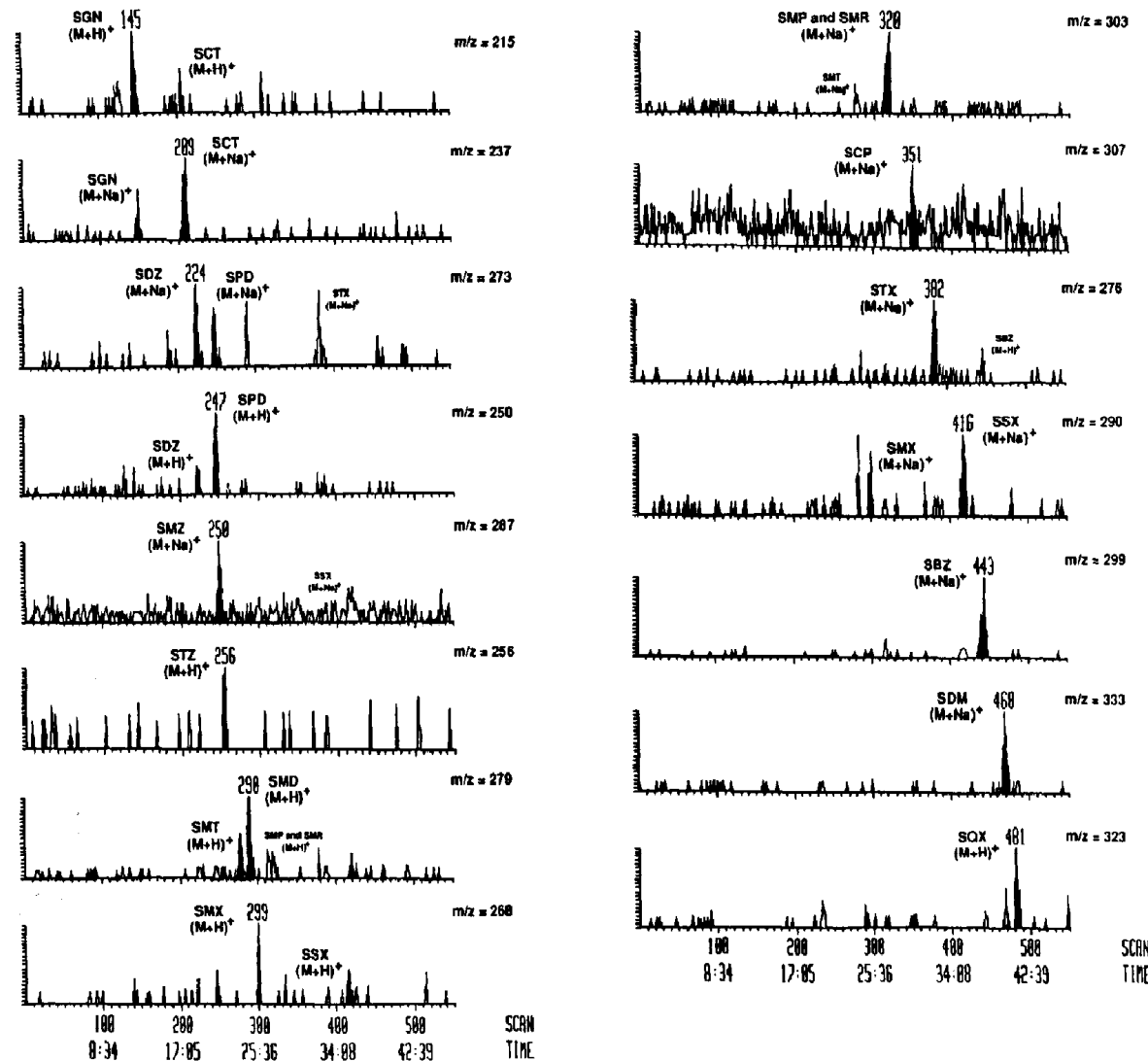

Figure 5. The selected ion chromatograms observed for the $(\mathrm{M}+\mathrm{H})^{+}$and $(\mathrm{M}+\mathrm{Na})^{+}$ions of the sulfonamides from nCLC/ESI/MS of a mix of 19 standards. The amount of each injected on column ranged from $30 \mathrm{pmol} S O X$ to $40 \mathrm{pmol} S C T$ and SGN. The analytical column was the same as in Figure $4 \mathrm{~A}$. The mobile phase utilized a gradient from $0 \% \mathrm{~B}$ to $50 \% \mathrm{~B}$ over $1 \mathrm{~h}$ where solvent $\mathrm{A}$ was water containing $0.1 \%$ TFA and solvent $B$ was acetonitrile containing $0.1 \%$ TFA. All other experimental conditions as in Figure 4A. 
Nineteen standards were injected, but only 16 were actually observed routinely (Figure 5). This chromatographic run employed a gradient from $0 \%$ B to $50 \%$ B over $1 \mathrm{~h}$ where solvent $A$ was water containing $0.1 \%$ TFA and solvent B was acetonitrile containing $0.1 \%$ TFA. SNL proved to be a problem throughout and although we could readily acquire spectra via flow injection analysis, it was never seen when chromatographed on-line. Under these conditions SMP and SMR coeluted, resulting in a broad peak in the selected ion chromatogram for $m / z=303[(\mathrm{M}+$ $\left.\mathrm{Na}^{+}\right]$. These ions could not be distinguished by mass because they have the same molecular weight. An additional difficult analyte was SML, which eluted between SMP and SCP and was seen in some chromatographic runs but not in that illustrated. The signal for SCP in the $m / z=307$ chromatogram was weak because SCP was one of the least sensitive of the sulfonamides studied. The $30 \mathrm{pmol}$ injected is close to the detection limits for the sulfonamides using this system. The $S / N$ ratios of the peaks due to the protonated molecule ions were considerably closer to the detection limits than expected, when compared to those obtained in Figure $4 \mathrm{~b}$. This is attributed to the increased formation of sodiated molecule ions within this sample.

Of further interest to us was the possible application of CZE to the determination of the sulfonamides.
This was only attempted for the mixture of nine sulfonamides. An initial problem we noted when performing CZE with the power supply at $+30 \mathrm{kV}$ and $10 \mathrm{mM}$ buffer was that there was sufficient conductivity across the column such that the needle voltage, and, thus, the measured spray current, increased markedly. This meant that the operating conditions set prior to initiation of the CZE separation were altered when the CZE voltage was applied, and it became necessary to lower the voltage on the needle once the run had commenced. We restricted our choice of CZE buffers to those which are volatile. Ammonium acetate $(0.01 \mathrm{M}, \mathrm{pH} 7)$ was the buffer of choice, but we found that overloading of the CZE column readily occurred and the upper limit of loading was very close to the detection limit of the mass spectrometer. Use of a more concentrated buffer to increase column capacity was unsuccessful because the needle voltage (and thus spray current) increased so much that operation was impossible. When CZE was performed with ammonium acetate buffer $(0.02 \mathrm{M}, \mathrm{pH} 7)$ the measured voltage on the needle was $10 \mathrm{kV}$.

The sulfonamides were separated as negative ions, but use of the acetic acid in the makeup flow allowed their detection as positive ions in the mass spectrometer. This may have reduced sensitivity depending on the efficiency of protonation in the spray. Preliminary results indicate that this process is not as efficient in

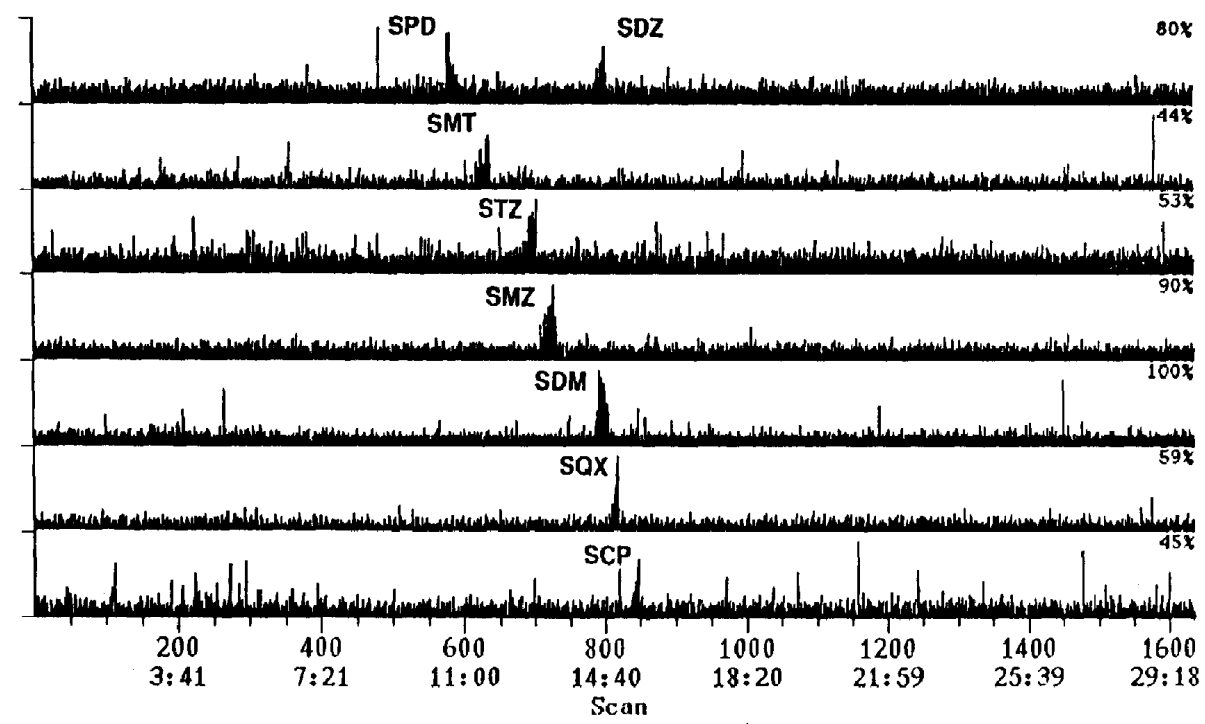

Figure 6. The selected ion electropherograms of the $(\mathrm{M}+\mathrm{H})^{+}$ions of the sulfonamides from CZE/ESI/MS of a mixture of the sulfonamides in Figure 4A. The amount of each injected onto the column was $\sim 2$ pmol. The column was a $1.1-\mathrm{m}$ length of $75 \mu \mathrm{m}$ i.d. $150 \mu \mathrm{m}$ o.d. fused silica capillary tubing. The buffer was $0.01 \mathrm{M}$ ammonium acetate adjusted to $\mathrm{pH} 7$ with ammonium hydroxide. The voltage drop across the column was $27 \mathrm{kV}$. Electrospray conditions as in Figure $4 \mathrm{~A}$ except spectra were acquired from 230 to $350 \mathrm{u}$ at $1 \mathrm{~s}$ per scan. The number of theoretical plates ranges from $17,000(\mathrm{SDM})$ to $106,000(\mathrm{SQX})$. 
ESI as it is in CZE/coaxial continuous-flow FAB [23]. We were interested in the detection limits of the system for the sulfonamides using full-scan acquisitions rather than selected ion monitoring. From the electropherograms of the protonated molecule ions of the sulfonamides it can be seen that they could be separated readily under these conditions (Figure 6). SMP is not shown because it yielded a broad peak which was difficult to distinguish from the background even at this level. This separation corresponds to -2 pmol of analyte being injected onto the column, giving a factor of 10 improvement in sensitivity and a factor of 3 decrease in time needed to obtain an equivalent separation using nCLC. Using this system, the upper limit of loading onto the column was close to the lower limit of detection of our mass spectrometer and the dynamic range was very small. Consequently, the analyte amounts were close to the detection limits and this meant that spikes due to electrical noise seemed relatively large compared to the peaks of interest. From these experiments it must be concluded that nCLC and CZE are complementary techniques.

\section{Conclusion}

Both nCLC/ESI/MS and CZE/ESI/MS have been shown to be applicable to the determination of mixtures of sulfonamides where full-scan spectra can be obtained at the low picomole level. The narrower peaks obtained using CZE provide enhanced detection limits but in nCLC sample preconcentration is simple, which helps overcome this limitation. This sample preconcentration capability may prove useful in the analysis of environmental or biomedical samples. The advantage of CZE is the rapidity of the technique. In our opinion the techniques are complementary and both are useful for the determination of these compounds.

It is possible to induce fragmentation of the sulfonamides by increasing the skimmer voltage. This can be used to provide a limited means of discriminating between compounds of identical molecular weight. For investigation of a class of compounds it can be used to produce a common fragment ion, and thus, a confirmation of the presence of analyte in a sample.

\section{References}

1. Paulson, G. D.; Mitchell, A. D.; Zaylskie, R. G. J. Assoc. Off. Anal. Chem. 1985, 68, 1000-1006.

2. Belliardo, F. J. A pic. Res. 1981, 20, 44-48.

3. Nose, N.; Hoshino, Y.; Kikuchi, Y.; Horie, M.; Saitoh, K.; Kawachi, T.; Nakazawa, H. J. Assoc. Off. Anal. Chem. 1987, $70,714-717$.

4. Seymour, D.; Rupe, B. D. J. Pharm. Sci. 1980, 69, 701-703.

5. Torel, J.; Cillard, J.; Cillard, P.; Vie, M. J. Chromatogr. 1985, 330, 425-428.

6. Paulson, G. D.; Giddings, J. M.; Lamoreux, C. $\mathrm{H}_{\text {; }}$ Mansager, E. R.; Struble, C. B. Drug Metab. Dispos. 1981, 9, $142-146$.
7. Haagsma, N.; Pluijmakers, G. J. M.; Aerts, M. M. L.; Beek, W. M. J. Biomed. Chromatogr, 1987, 2, 41-45.

8. Long, A. R.; Short, C. R.; Barker, S. A. J. Chromatogr. 1990, $502,87-94$.

9. Haagsma, N.; van de Water, C. I. Chromatogr. 1985, 333, 256-261.

10. Brumley, W. C.; Zhao Min; Matusik, J. E.: Roach, J. A. G; Barnes, C. J.; Sphon, J. A.; Fazio, T. Anal. Chem. 1983, 55, 1405-1409.

11. Parks, O. W. J. Assoc. Off. Anal. Chem. 1985, 68, 20-22.

12. Cross, R. F. I. Chromatogr. 1989, 478, 422-428.

13. Finlay, E. H. M.; Games, D. E.; Startin, J. R.; Gilbert, J. Biomed. Environ. Mass Spectrom. 1986, 13, 633-639.

14. Berry, A. J; Games, D. E.; Perkins, J. R. J. Chromatogr. 1986, 363, 147-158.

15. Perkins, J. R.; Games, D. E.; Startin, J. R.; Gilbert, J. J. Chromatogr. 1991, 540, 239-256.

16. Vree, T. B.; Hekster, Y. A.; Baars, A. M.; Damsma, J. E.; van der Kleijn, F. J. Chromatogr. 1978, 146, 103-112.

17. Patthy, M. J. Chromatogr. 1983, 275, 115-125.

18. Aerts, M. M. L.; Beek, W. M. J.; Brinkman, U. A. T. J. Chromalogr. 1988, 435, 97-112.

19. Simpson, R. M.; Suhre, F. B.; Shafer, J. W. I. Assoc. Off. Anal. Chem. 1985, 68, 23-26.

20. Henion, J. D.; Thomson, B. A.; Dawson, P. H. Anal. Chem. 1982, 54, 451-456.

21. Pleasance, S.; Blay, P.; Quilliam, M. A.; O'Hara, G. I. Chromatogr., in press.

22. Bruins, A. P.; Covey, T. R.; Henion, J. D. Anul. Chem. 1987, 59, 2642-2646.

23. Bruins, A. P.; Weidolf, L. O. G.; Henion, J. D.; Budde, W. L. Anal. Chem. 1987, 59, 2647-2652.

24. Covey, T. R.; Bruins, A. P.; Henion, J. D. Org. Mass Spectrom. 1988, 23, 178-186.

25. Weidolf, L. O. G.; Lee, E. D,; Henion, J. D. Biomed. Environ. Mass Spectrom. 1988, 15, 283-289.

26. Lee, E. D.; Henion, J. D.; Covey, T. R. J. Microcol. Sep. 1989, 1, 14-18.

27. Lee, E. D.; Henion, J. D. I. Am. Soc. Mass Spectrom. 1990, 1. 158-165.

28. Mueck, W. M.; Henion, J. D. Biomed. Environ. Mass Spectrom. 1990, 19, 37-51

29. Pleasance, S.; Quilliam, M. A.; de Freitas, A. S. W.; Marr, J. C.; Cembella, A. D. Rapid Commun. Mass Spectrom. 1990, 4, 206-213.

30. Allen, M. H.; Field, F. H.; Vestal, M. L. In Proceedings of the 38th ASMS Conference on Mass Spectrometry and Allied Topics, Tucson, AZ, June 3-8, 1990, pp 431-432.

31. Henion, J. D.; Huang E. C.; Duffin, K. L. In Proceedings of the 38th ASMS Conference on Mass Spectrometry and Allied Topics, Tucson, AZ, June 3-8, 1990, pp 14-15.

32. Quilliam, M. A.; Pleasance, S.; Marr, J. C. In Proceedings of the 38th ASMS Conference on Mass Spectrometry and Allied Topics, Tucson, AZ, June 3-8, 1990, pp 1150-1151.

33. Pleasance, S.; Quilliam, M. A.; Boyd, R. K.; Thibault, P. In Procedings of the 38th ASMS Conference on Mass Spectrometry and Allied Topics, Tucson, AZ, June 3-8, 1990, pp 381-382.

34. McLuckey, S. A.; Van Berkel, G. J.; Glish, G. L; Huang, E. C.; Henion J. D. Anal. Chem. 1991, 63, 375 383.

35. Hemling, M. E.; Roberts, G. D.; Johnson, W.; Carr, S. A; Covey, T. R. Biomed. Environ. Mass Spectrom. 1990, 19, 677-691.

36. Feistner, G. J. In Proceedings of the 38th ASMS Conference on Mass Spectrometry and Allied Topics, Tucson, AZ, June 3-8, 1990, pp 144-145. 
37. Huang, E. C.; Henion, J. D. Anal. Chem. 1991, 63, 732-739. 38. Hail, M.; Schwartz, J; Mylchreest, I. C.; Seta, K.; Lewis, S.; Zhou, J.; Jardine, I.; Liu, J.; Novotny, M. In Proceedings of the 38th ASMS Conference on Mass Spectrometry and Allied Topics, Tucson, AZ, June 3-8, 1990, pp 353-354.

39. Hail, M.; Lewis, S.; Jardine, I.; Liu, J.; Novotny, M. J. Microcol. Sep. 1990, 2, 285-292.

40. Moseley, M. A.; Deterding, L. J.; Tomer, K. B.; Jorgenson, J. W. I. Chromatogr. 1990, 516, 167-173.

41. Moseley, M. A.; Deterding, L. J.; Tomer, K. B.; Jorgenson, J. W. Anal. Chem. 1991, 63, 109-114.

42. Moseley, M. A.; Deterding, L. J., Tomer, K. B.; Jorgenson, J. W. Anal. Chem., 1991, 63, 1467-1473.

43. Deterding, L. J.; Parker, C. E.; Perkins, J. R.; Moseley, M. A.; Jorgenson, J. W.; Tomer, K. B. J. Chromatogr., 1991, 554, 329-338.

44. de Wit, J. S. M.; Parker, C. E.; Tomer, K. B.; Jorgenson, J. W. Anal. Chem. 1987, 59, 2400-2404.

45. de Wit, J. S. M.; Parker, C. E.; Jorgenson, J. W.; Tomer, K. B. Biomed. Environ. Mass Spectrom. 1988, 17, 47-53.

46. de Wit, J. S. M.; Deterding, L. J.; Moseley, M. A.; Tomer, K. B.; Jorgenson, J. W. Rapid Commun. Mass Spectrom. 1988, 2, 100-104.

47. Moseley, M. A.; Deterding, L. J.; de Wit, J. S. M.; Tomer, K. B.; Kennedy, R. T.; Bragg, N.; Jorgenson, J. W. Anal. Chem. 1989, 61, 1577-1584.

48. Moseley, M. A.; Deterding, L. J.; Tomer, K. B.; Jorgenson, J. W. Rapid Commun. Mass Spectrom. 1989, 3, 87-93.

49. Escoffter, B. H.; Parker, C. E.; Mester, T. C.; de Wit, J. S. M.; Corbin F. T.; Jorgenson, I. W.; Tomer, K. B. J. Chromatogr. 1989, 474, 301-316.

50. Moseley, M. A.; Deterding, L. J.; Tomer, K. B.; Jorgenson, J. W. J. Chromatogr. 1989, 480, 197-209.

51. Parker, C. E.; Perkins, J. R.; Tomer, K. B.; Shida, Y.; O'Hara, K.; Kono, M. J. Am. Soc. Mass Spectrom., manuscript submitted for publication.

52. Jorgenson, J. W.; Lukacs, K. D. Science 1983, 222, 266-272.

53. Olivares, J. A.; Nguyen, N. T.; Yonker, C. R.; Smith, R. D. Anal. Chem. 1987, 59, 1230-1232.

54. Smith, R. D.; Olivares, J. A.; Nguyen, N. T.; Udseth, H. R. Anal. Chem. 1988, 60, 436-441.

55. Smith, R. D.; Barinaga, C. J.; Udseth H. R. Anal. Chem. 1988, 60, 1948-1952.

56. Loo, J. A.; Jones, H. K.; Udseth, H. R.; Smith, R. D. J. Microcol. Sep. 1989, 1, 223-229.

57. Loo, J. A.; Udseth, H. R.; Smith, R. D. Anal. Biochem. 1989, $179,404-412$

58. Smith, R. D., Loo, J. A.; Barinaga, C. J.; Edmonds, C. G.; Udseth, H. R. J. Chromatogr, 1989, 480, 211-232.

59. Smith, R. D.; Loo, J. A.; Edmonds, C. G.; Barinaga, C. J.; Udseth, H. R. J. Chromatogr. 1990, 516, 157-165.

60. Moseley, M. A,; Shabanowitz, J.; Hunt, D. F.; Tomer K. B.; Jorgenson, J. W. J. Amer. Soc. Mass Spectrom., manuscript submitted for publication.

61. Shabanowitz, J.; Moseley, M. A.; McCormack, A.; Michel, H.; Martino, P.; Hunt, D. F.; Tomer, K. B.; Jorgenson, J. W. In Proceedings of the 38th ASMS Conference on Mass Spectrometry and Allied Topics, Tucson, AZ, June 3-8, 1990, PP 1497-1498.

62. Moseley, M. A.; Jorgenson, J. W.; Tomer, K. B.; Hunt, D. F.; Alexander, J. E.; McCormack, A. L.; Martino, P. A.; Michel, H.; Shabanowitz, J.; Sherman, N. In Techniques in
Protein Chemistry II, Villafranca, J. J., Ed. Academic: New York, 1991, pp. 441-454.

63. Udseth, H. R.; Barinaga, C. J.; Smith, R. D. In Proceedings of the 38th ASMS Conference on Mass Spectrometry and Allied Topics, Tucson, AZ, June 3-8, 1990, pp 1210-1211.

64. Lee, E. D.; Mueck, W.; Henion, J. D.; Covey, T. R. J. Chromatogr. 1988, 458, 313-321.

65. Mueck, W. M.; Henion, J. D. I. Chromatogr. 1989, 495, 41-59.

66. Lee, E. D.; Mueck, W.; Henion, J. D.; Covey, T. R. Biomed. Environ. Mass Spectrom. 1989, 18, 844-850.

67. Johansson, M.; Huang, E.; Henion, J.; Zweigenbaum, J. In proceedings of the 38th ASMS Conference on Mass Spectrometry and Allied Topics, Tucson, AZ, June 3-8, 1990, pp 377-378.

68. Lee, E. D.; Mueck, W.; Henion, J. D.; Covey, T. R. Biomed. Enviton. Mass Spectrom. 1989, 18, 253-257.

69. Henion, J. D. Presented at the Beckman Discovery Seminar, Research Triangle Park, NC, Oct. 4, 1990.

70. Wainwright, A. J. Micrecol. Sep. 1990, 2, 166-175.

71. Lux, J. A.; Yin, H.-F.; Schomburg, G. Chromatographia 1990, 30, 7-15.

72. Hershberger, L. W.; Callis, J. B.; Christian, G. D. Anal. Chem. 1979, 51, 1444-1446.

73. Rose, D. J. Jr.; Jorgenson, J. W. J. Chromatogr. 1988, 447, 117-131.

74. Tomer, K. B.; Moseley, M. A. In Continuous-Flow Fast Atom Bombardment Mass Spectrometry, Caprioli, R. M., ed.; Wiley \& Sons: New York, 1990; pp 121-136.

75. Kambara, H.; and Kanomata, I. Anal. Chem. 1977, 49, 270-275.

76. Caldecourt, V. J.; Zakett, D.; and Tou, J. C. Int. J. Mass Spectrom. Ion Phys. 1983, 49, 233-251.

77. Loo, J. A.; Udseth, H. R.; and Smith, R. D. Rapid Commun. Mass Spectrom. 1988, 2, 207-210.

78. Yinon, J.; Jones, T. L.; and Betowski, L. D. In Proceedings of the 38th ASMS Conference on Mass Spectrometry and Allied Topics, Tucson, AZ, June 3-8, 1990, pp 43-44.

79. Voyksner, R. D.; Pack, T.; Cornish, T. J. In Proceedings of the 38th ASMS Conference on Mass Spectrometry and Allied Topics, Tucson, AZ, June 3-8, 1990, pp 1218-1219.

80. Heeremans, C. E. F.; van der Hoeven, R. A. M.; Niessen, W. M. A.; Tjaden, U. R.; van der Greef, J.; Nibbering, N. M. M. In Procedings of the 38th ASMS Conference on Mass Spectrometry and Allied Topics, Tucson, AZ, June 3-8, 1990, pp 1216-1217.

81. Katta, V.; Chowdhury, S. K.; Chait, B. T. Anal. Chem. 1991, 63, 174-178.

82. Katta, V.; Chowdhury, S. K.; Chait, B. T. In Proceedings of the 38th ASMS Conference on Mass Spectrometry and Allied Topics, Tucson, AZ, June 3-8, 1990, pP 214-215.

83. Loo, J. A.; Edmonds, C. G.; Udseth, H. R.; Smith, R. D. In Proceedings of the 38th ASMS Conference on Mass Spectrometry and Allied Topics, Tucson, AZ, June 3-8, 1990, pp 140-141.

84. Ogorzalek-Loo, R. R.; Udseth, H. R.; Loo, J. A.; Smith, R. D. In Proceedings of the 38th ASMS Conference on Mass Spectrometry and Allied Topics, Tucson, AZ, June 3-8, 1990, PP 142-143.

85. Van Berkel, G. J.; McLuckey, S. A.; Glish, G. L. Anal. Cherr. 1991, 63, 1098-1109.

86. Davis, R.; Hurst, D. T.; Taylor, A. R. I. Appl. Chem. Biotechnol. 1977, 27, 543-548. 